\title{
Gene expression in sheep cumulus-oocyte complexes meiotically inhibited with roscovitine
}

\author{
Letícia Ferrari Crocomo $^{\mathrm{a}, *}$, Wolff Camargo Marques Filho ${ }^{\mathrm{a}}$, Camila Louise Ackermann ${ }^{\mathrm{a}}$, \\ Paula Fernanda de Lima ${ }^{\mathrm{b}}$, José Buratini Junior ${ }^{\mathrm{b}}$, Fernanda da Cruz Landim-Alvarenga ${ }^{\mathrm{a}}$, \\ Sony Dimas Bicudo ${ }^{a}$
}

a Department of Animal Reproduction and Veterinary Radiology, School of Veterinary Medicine and Animal Science, UNESP, Distrito de Rubião Junior s/ ${ }^{\circ}$, 18618-970, Botucatu, Brazil

${ }^{\mathrm{b}}$ Department of Physiology, Institute of Biosciences, UNESP, Distrito de Rubião Junior s/ $n^{\circ}, 18618-970$, Botucatu, Brazil

\section{A R T I C L E I N F O}

\section{Article history:}

Received 11 May 2015

Received in revised form 8 October 2015

Accepted 10 October 2015

Available online 23 October 2015

\section{Keywords:}

mRNA

qRT-PCR

Nuclear status

Cumulus expansion

Meiosis inhibitor

Ovine

\begin{abstract}
A B S T R A C T
The majority of mammalian oocytes destined for in vitro maturation (IVM) have not undergone all molecular and structural changes necessary for competence acquisition to support the fertilization and early embryogenesis. In this context, different methods able to provide a transient arrest of meiosis resumption have been tested in order to improve the in vitro developmental potential of oocytes. Based on that, our study aimed to evaluate the effect of temporary meiosis inhibition using roscovitine on gene expression in sheep oocytes and cumulus cells. For this, cumulus-oocyte complexes (COCs) were cultured for $6 \mathrm{~h}$ in modified TCM199 medium with (Rosco) and without (Control) $75 \mu \mathrm{M}$ roscovitine. Subsequently, they were in vitro matured for a further $18 \mathrm{~h}$ in inhibitor-free TCM199 medium supplemented with gonadotropins. At 0,6 and $24 \mathrm{~h}$ of culture, nuclear status of oocytes and expression of selected genes were evaluated by Hoescht staining and qRT-PCR, respectively. The analysis of oocyte chromatin organization revealed that roscovitine efficiently inhibited the meiosis of sheep oocytes for $6 \mathrm{~h}$ and its action was completely reversed after $18 \mathrm{~h}$ of in vitro maturation in inhibitor-free medium. Besides, no detrimental effect on cumulus expansion was observed. The expression profile of most investigated genes in cumulus cells (PTX3, GREM1, GLUT1, PTGS2, ALK5, ALK6) and oocytes (ZAR1, NLRP5, SOD1, BMP15, GDF9) was similar between Control and Rosco treatments and the ratio BCL2/BAX was maintained in both cell types even in the presence of roscovitine. These results indicate that reversible meiotic arrest promoted by roscovitine, at the concentration and exposure time studied, neither impaired nor improved the expression of investigated genes in sheep oocytes and cumulus cells. Moreover, the efficiency of temporary meiotic arrest and the absence of deleterious effect on COCs suggest that roscovitine provides a useful method for transportation or manipulation of sheep oocytes at onset of maturation. However, further investigations are necessary to evaluate the benefits of roscovitine treatment on in vitro development of sheep embryos and its effects on cellular ultrastructure.
\end{abstract}

(c) 2015 Elsevier B.V. All rights reserved.

\section{Introduction}

Mammalian oocytes enter into meiosis during the intrauterine life and remain arrested at diplotene stage of prophase-I until near ovulation. In response to preovulatory surge of $\mathrm{LH}$, meiotic division resumes and proceeds to metaphase II (Mehlmann, 2005). During this diplotene arrest, oocytes display an enlarged nucleus,

\footnotetext{
* Corresponding author at: Rua dos Girassóis, n.278, Bairro Convívio, CEP 18605240 Botucatu, S.P., Brazil.

E-mail address: leticia.crocomo@gmail.com (L.F. Crocomo).
}

called germinal vesicle, which contains lampbrush chromosomes composed of regions with side loops of decondensed and transcriptionally active chromatin (Andraszek and Smalec, 2011). So, oocytes at germinal vesicle stage are able to produce and store all mRNAs and proteins required (Sirard, 2001).

With meiosis resumption, however, this transcriptional activity is interrupted, due to chromatin condensation, and restored only with embryonic genome activation when the embryo begins to transcribe its own mRNAs. Therefore, the processes of oocyte maturation, fertilization and pre-implantation development depend on maternal mRNAs synthesized and stored during oogenesis (Brevini-Gandolfi and Gandolfi, 2001; Sirard, 2001). In the course of 

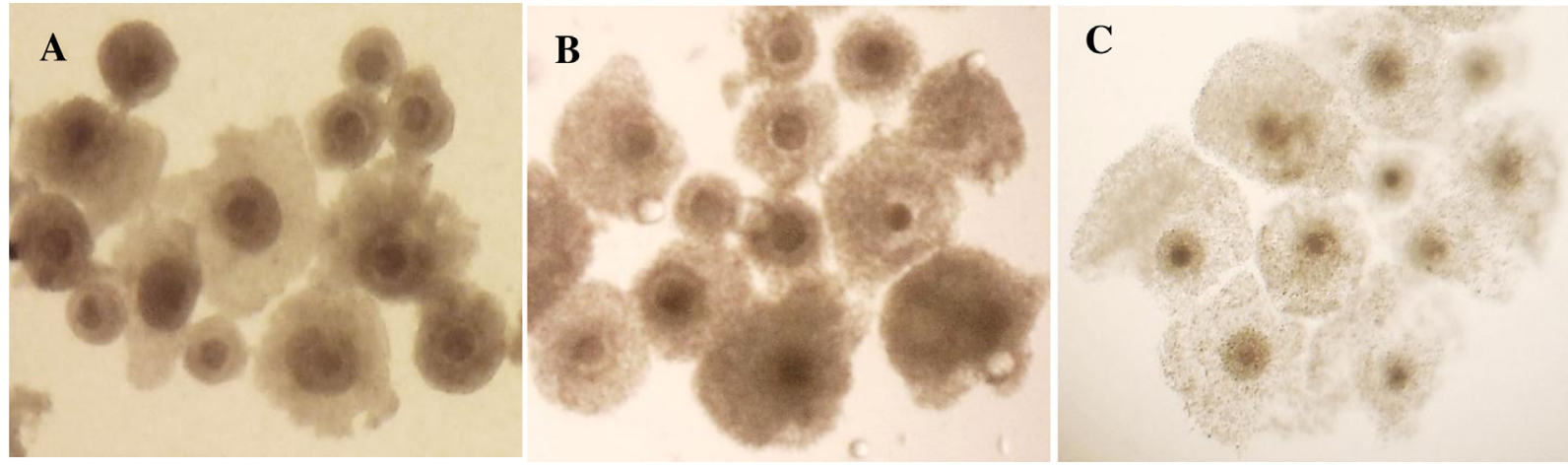

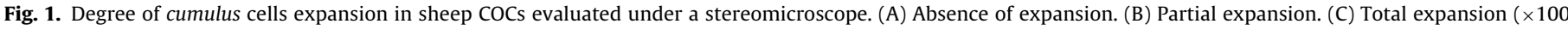
magnification).

acquiring competence to resume and complete the meiosis, oocytes also undergo important structural changes related to the morphology and distribution of organelles (Ferreira et al., 2009). All these events that characterize the nuclear and cytoplasmic maturation are controlled by low molecular weight peptides transferred from cumulus cells to oocyte through Gap junctions. Likewise, many critical functions of granulosa cells are regulated by oocyte-secreted factors (Sugiura and Eppig, 2005).

In contrast, when oocytes are removed from their follicles and transferred to a suitable culture medium, meiosis spontaneously resumes regardless of the cytoplasmic maturation stage (Pincus and Enzmann, 1935). So, most oocytes destined to in vitro maturation have not yet undergone all molecular and structural changes necessary to competence acquisition (Gilchrist and Thompson, 2007). In this context, the temporary arrest of meiosis with cyclindependent kinase (CDK) inhibitors has been proposed as strategy to provide time enough for the oocyte to complete its capacitation (Mermillod et al., 2000; Han et al., 2006).

The roscovitine is a CDK inhibitor that competes for ATP-binding domain on catalytic subunit of M-phase promoting factor, preventing its activation (Meijer et al., 1997). The reversible meiotic arrest promoted by roscovitine and its effect on embryo development has been demonstrated in several animal species as bovine (Mermillod et al., 2000), goat (Han et al., 2006), cat (Sananmuang et al., 2010), pig (Romar and Funahashi, 2006) and horse (Franz et al., 2003). The action of this inhibitor on gene expression in oocytes and cumulus cells, however, has not been extensively investigated. Furthermore, no similar information has been reported in sheep COCs. Based on that, the present study aimed to evaluate the effect of temporary arrest of meiosis, using the CDK inhibitor roscovitine, on relative abundance of transcripts associated with developmental competence in sheep oocytes and cumulus cells.

\section{Materials and methods}

All chemicals used were purchased from Sigma Chemical Co. (Sigma-Aldrich Corp., St. Louis, MO, USA), unless otherwise indicated.

\subsection{Collection of cumulus-oocyte complexes}

Ovaries of adult sheep were collected at slaughterhouse and transported to laboratory within $1-2 \mathrm{~h}$ in sterile saline solution $(0.9 \% \mathrm{NaCl})$ at $32^{\circ} \mathrm{C}$. All follicles with diameter of $2-6 \mathrm{~mm}$ were aspirated with a 20 gauge needle attached to $10 \mathrm{~mL}$ syringe containing 0.5 mL Hepes-buffered TCM199 (12340-030; Gibco, Invitrogen Co., USA) supplemented with $50 \mathrm{IU} / \mathrm{mL}$ heparin. Only COCs with several intact cumulus cell layers and homogeneous ooplasm were selected (Shirazi et al., 2010).

\subsection{Meiosis inhibition and reversibility}

After washes in Hepes-buffered TCM 199, the selected COCs were transferred to basic maturation medium composed of TCM 199 with Earle's salts (11150059; Gibco, Invitrogen Co., USA), $0.3 \mathrm{mM}$ sodium pyruvate, $75 \mu \mathrm{g} / \mathrm{mL}$ penicillin, $10 \%$ fetal bovine serum (10437; Gibco, Invitrogen Co., USA) and $100 \mu \mathrm{M}$ cysteamine (Control) added of $75 \mu \mathrm{M}$ roscovitine (Rosco). About 25 COCs were cultured, for $6 \mathrm{~h}$, in $100 \mu \mathrm{L}$ droplets of medium placed in 96 well plates without oil overlay at $38.5^{\circ} \mathrm{C}$ and $5 \% \mathrm{CO}_{2}$ in air. The stock solution of roscovitine $(1 \mathrm{mg} / \mathrm{mL})$ was prepared in dimethylsulphoxide, aliquoted and stored at $-20^{\circ} \mathrm{C}$ until use.

In order to enable the reversibility of roscovitine action, after $6 \mathrm{~h}$ of culture, COCs from Rosco treatment were washed in Hepesbuffered TCM 199 and in vitro matured, for a further $18 \mathrm{~h}$, in basic maturation medium supplemented with $0.1 \mathrm{IU} / \mathrm{mL}$ FSH (Folltropin ${ }^{\circledR}$, Bioniche Co., Belleville, ON, Canada) and $0.1 \mathrm{IU} / \mathrm{mL}$ LH (Lutropin- ${ }^{\circledR}$, Bioniche Co.). COCs from Control were submitted to this same procedure. The in vitro maturation was performed in 96 well plates without mineral oil overlay at $38.5^{\circ} \mathrm{C}$ and $5 \% \mathrm{CO}_{2}$ in air. The inhibitor concentration and culture conditions were based on our preliminary studies (Crocomo et al., 2015a,b,c).

\subsection{Assessment of cumulus expansion and oocyte nuclear status}

Under a stereomicroscope, COCs were evaluated and classified according to the degree of cumulus expansion (Heidari Amale et al. 2011) as: total cumulus expansion (significant dispersion of all cells layers); partial cumulus expansion (subtle dispersion of outer cells layers); and absence of cumulus expansion (cells strongly adhered to each other and to the pellucid zone) (Fig. 1).

For evaluation of oocyte chromatin organization, cumulus cells were removed by repeated pipetting and denuded oocytes were transferred to droplets of Hoechst 33342 in glycerol $(10 \mu \mathrm{g} / \mathrm{mL})$ on a glass slide. Under a fluorescence inverted microscope (Leica ${ }^{\circledR}$ DMIRB), oocytes were examined and classified according to the stage of nuclear maturation (Shirazi et al., 2010) as germinal vesicle (GV), germinal vesicle breakdown (GVBD), metaphase I (MI) and metaphase II (MII). Those with altered nuclear structure were classified as degenerate (Deg) (Fig. 2).

\subsection{RNA isolation and reverse transcription (RT)}

Oocytes were completely stripped from their cumulus cells by repeated pipetting in phosphate-buffered saline (PBS). The PBS droplet containing cumulus cells were centrifuged for $5 \mathrm{~min}$ at $700 \mathrm{~g}$ and supernatant was removed. Finally, oocytes and cumulus cells were frozen at $-80^{\circ} \mathrm{C}$ with $350 \mu \mathrm{L}$ of RNA extraction 

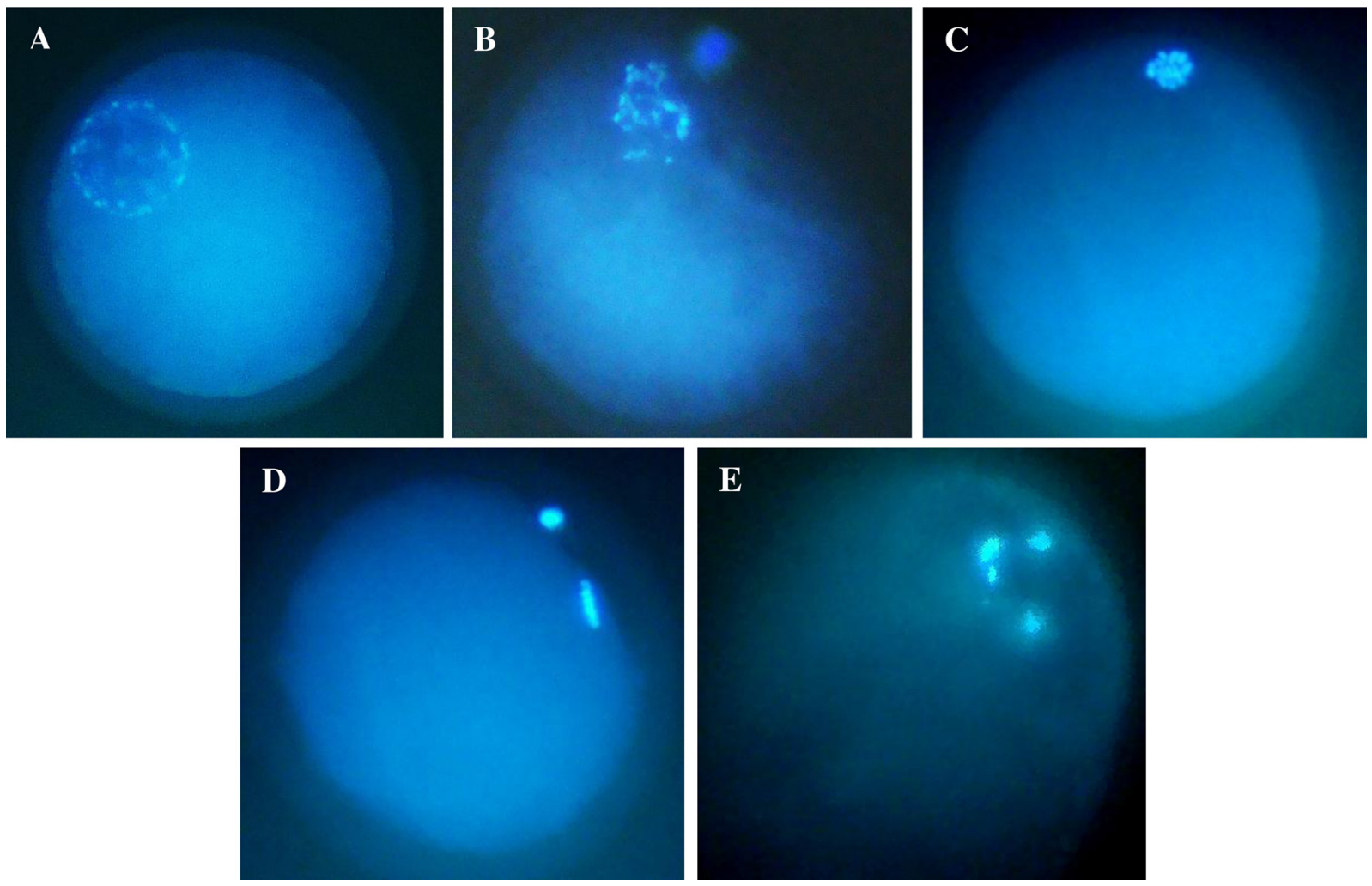

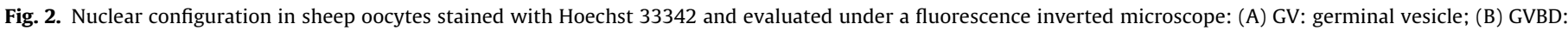
germinal vesicle breakdown; (C) MI: metaphase I; (D) MII: metaphase II; (E) Deg: degenerate ( $\times 200$ magnification).

lysis buffer in their respective $1.5 \mathrm{~mL}$ sterile tubes. Total RNA was extracted from four pools of 25 oocytes and their corresponding cumulus cells using the RNeasy Mini Kit (Qiagen, Mississauga, ON, CA) according to manufacturer's instructions and eluted in $30 \mu \mathrm{L}$ RNAse-free water. After incubation with DNase I (Invitrogen, São Paulo, Brazil), total RNA was reverse transcribed with Sensiscript and Omniscript RT Kit (Qiagen, Mississauga, ON, CA) for oocyte and cumulus samples, respectively, using Oligo-dT (Invitrogen) primers for both.

\subsection{Relative quantification by real-time $P C R$}

The expression of SOD1, NLRP5, ZAR1, BMP15 and GDF9 genes was evaluated in oocytes whereas the expression of GREML1, PTX3, GLUT1, PTGS2, ALK5 and ALK6 genes was analyzed in cumulus cells. The BAX and BCL2 genes were evaluated in both cell types. Real time RT-PCR analysis was performed using the ABI Prism 7500 Sequence Detection System with Power Sybr Green PCR Master Mix (Applied Biosystems). Reactions were performed in $25 \mu \mathrm{L}$ volumes and PCR cycling conditions were $95^{\circ} \mathrm{C}$ for $10 \mathrm{~min}$ followed by 40 cycles of denaturing at $95^{\circ} \mathrm{C}$ for $10 \mathrm{~s}$ and annealing for $1 \mathrm{~min}$. The primers sequences, fragment size and annealing temperatures for each gene are shown in Table 1.

Each sample was analyzed in duplicate, and the specificity of PCR products was assessed by melting curve analysis and amplicon size determination by electrophoresis in agarose $2 \%$. Among three genes tested (ACTB, GAPDH, CYC-A) with geNorm program, Cyclophilin$A(C Y C-A)$ was selected as the most stable housekeeping gene. The relative expression of each gene was calculated using the $\Delta \Delta \mathrm{Ct}$ method with efficiency correction (Pfaffl, 2001). Mean efficiency values for each gene were calculated from the amplification profile of individual samples with LinRegPCR software (Ramakers et al., 2003).

\subsection{Experimental design}

The experimental design was completely randomized with two experiments and five treatments (Immature, Control $6 \mathrm{~h}$, Rosco $6 \mathrm{~h}$, Control $6+18 \mathrm{~h}$ and Rosco $6+18 \mathrm{~h}$ ) each one. The experiment 1 was developed to evaluate the efficiency of roscovitine to temporarily inhibit the meiosis of sheep oocytes. The experiment 2 aimed to analyze the effect of meiotic inhibition on relative abundance of mRNA in oocytes and cumulus cells.

\subsubsection{Experiment 1 - meiosis inhibition and reversibility}

At the end of $6 \mathrm{~h}$ culture, a sample of COCs from Control and Rosco was evaluated for cumulus expansion and nuclear maturation under a stereomicroscope and by Hoechst 33342 staining, respectively. Another sample of COCs was in vitro matured for a further $18 \mathrm{~h}$ in inhibitor-free medium and submitted to the same analysis cited above. Immature oocytes were stained soon after removal from follicle to evaluate the nuclear status before the culture $(0 \mathrm{~h})$.

\subsubsection{Experiment 2 - gene expression analysis}

After $6 \mathrm{~h}$ of culture in the absence (Control) and presence of roscovitine (Rosco) as well as after the in vitro maturation for a further $18 \mathrm{~h}$ in inhibitor-free medium, the oocytes and corresponding cumulus cells from each treatment were stored at $-80^{\circ} \mathrm{C}$ aiming the subsequent analysis of gene expression by qRT-PCR. An additional sample of immature oocytes and their cumulus cells was stored soon after removal from follicle $(0 \mathrm{~h})$.

\subsection{Statistical analysis}

The data of cumulus expansion and oocyte nuclear status were transformed into square root of $x+0.5$ and subjected to analysis of variance (ANOVA) according to factorial system with five treatments (Immature, Control 6 h, Rosco 6 h, Control 6+18 h and Rosco 
Table 1

Detail of primer sequences used for qRT-PCR in sheep cumulus-oocytes complexes.

\begin{tabular}{|c|c|c|c|c|c|}
\hline Gene & Primer Sequences $\left(5^{\prime}-3^{\prime}\right)$ & Cell analyzed & Annealing temperature $\left({ }^{\circ} \mathrm{C}\right)$ & Size (pb) & Genbank Acession no. \\
\hline CYC-A & $\begin{array}{l}\text { F: 5'-GCTGGCCCCAACACAAACGG-3' } \\
\text { R: 5'-AGCGCTCCATGGCTTCCACA-3' }\end{array}$ & Oocyte/cumuluscells & 58.5 & 127 & AY251270.1 \\
\hline ZAR1 & $\begin{array}{l}\text { F: 5'-TATCCGCTGGGAAAGTGCCTATGT-3' } \\
\text { R: 5'-TGATATCCTCCACTCGGTAAGGGT-3' }\end{array}$ & Oocyte & 59 & 116 & HМ037367.1 \\
\hline NLRP5 & $\begin{array}{l}\text { F: 5'-CTGACCTCTGAAGGCTGCAA-3' } \\
\text { R: 5'-GAACACAGCATCGCCATTCC-3' }\end{array}$ & Oocyte & 59.5 & 116 & XM_004015912.1 \\
\hline GDF9 & $\begin{array}{l}\text { F: 5'-GGCGCTTCCCAACAAATTCTTCCT-3' } \\
\text { R: 5'-TGGTTCAGCAAGGACCAAGTCTCA-3' }\end{array}$ & Oocyte & 59.5 & 153 & NM_001142888 \\
\hline BMP15 & $\begin{array}{l}\text { F: 5'-TAACCAGTGTTCCCTCCACCCTTT-3' } \\
\text { R: 5'-ATCCACCAGCTCACTGACAAGGTT-3' }\end{array}$ & Oocyte & 60 & 184 & NM_001114767.1 \\
\hline SOD1 & $\begin{array}{l}\text { F: 5'-CTGGGCAATGTGAAGGCTGACAAA-3' } \\
\text { R: 5'-TTTCCACCTCTGCCCAAGTCATCT-3' }\end{array}$ & Oocyte & 60 & 143 & FJ546075.1 \\
\hline BCL2 & $\begin{array}{l}\text { F: 5'-TTCGCCGAGATGTCCAGTCA-3' } \\
\text { R: 5'-TCCGAACTCAAAGAAGGCCACGAT-3' }\end{array}$ & Oocyte/cumuluscells & 59 & 129 & AY423861.1 \\
\hline BAX & $\begin{array}{l}\text { F: 5'-TCTACTTTGCCAGCAAACTGGTGC-3' } \\
\text { R: 5'-AAGGAAGTCCAATGTCCAGCCCAT-3' }\end{array}$ & Oocyte/cumuluscells & 60 & 92 & AY609317.1 \\
\hline PTGS2 & $\begin{array}{l}\text { F: 5'-GCCCAGCACTTCACCCATCAATTT-3' } \\
\text { R: 5'-AAAGGCGACGGTTATGCTGTCTCT-3' }\end{array}$ & Cumuluscells & 60 & 136 & NM_001009432.1 \\
\hline PTX3 & $\begin{array}{l}\text { F: 5'-GTTTCAGTGCCTGCATTTGGGTCA-3' } \\
\text { R: 5'-TCTCTCCACCCACCACAAGCATTA-3' }\end{array}$ & Cumuluscells & 60 & 141 & AM492193.1 \\
\hline GLUT1 & $\begin{array}{l}\text { F: 5'-GCCTTCACTGTCGTTTCGCTGTTT-3' } \\
\text { R: 5'-CACAAAGCCAAAGATGGCCACGAT-3' }\end{array}$ & Cumuluscells & 60 & 174 & U89029.1 \\
\hline GREMLIN & $\begin{array}{l}\text { F: 5'-CTGAAGCAGACCATCCACGA-3' } \\
\text { R: 5'-GGATGTGCCTGGGGATGTAG-3' }\end{array}$ & Cumuluscells & 60 & 100 & XM_004023159.1 \\
\hline ALK5 & $\begin{array}{l}\text { F: 5'-ACCTAATTCCACGAGACAGGCCAT-3' } \\
\text { R: 5'-GCAATGACAGCTGCCAGTTCAACA-3' }\end{array}$ & Cumuluscells & 60 & 160 & AY656799.1 \\
\hline ALK6 & $\begin{array}{l}\text { F: 5'-TGCTGGTCCAGAGGACAATAGCAA-3' } \\
\text { R: 5'-TCATGCCTCATCAACACCGTCTGA-3' }\end{array}$ & Cumuluscells & 60 & 187 & NM_001009431.1 \\
\hline
\end{tabular}

$6+18 \mathrm{~h}$ ), three parameters in the case of cumulus expansion (total, partial and absence) and five parameters in the case of oocyte nuclear status (GV, GVBD, MI, MII, Deg). Five replicates were performed for each parameter assessed. The means were compared by Tukey test at $5 \%$ probability. $P$-values less than 0.05 were considered statistically significant.

Regarding the gene expression, data of each gene were transformed into square root of $x+0.5$ and individually subjected to analysis of variance (ANOVA) according to completely randomized design with five treatments (Immature, Control 6 h, Rosco 6 h, Control $6+18 \mathrm{~h}$ and Rosco $6+18 \mathrm{~h}$ ) and four replicates. The means were compared by Tukey test at $5 \%$ probability. $P$-values less than 0.05 were considered statistically significant.

\section{Results}

\subsection{Experiment 1 - meiosis inhibition and reversibility}

According to Table 2, all immature COCs evaluated immediately after follicular aspiration $(0 \mathrm{~h})$ had compact cumulus cells, which significantly differed from that observed in the other treatments. After $6 \mathrm{~h}$ of culture, the percentage of COCs with absence of cumulus expansion in the Control and Rosco significantly prevailed over the rate of partial and total expansion. This rate of COCs with compact cumulus cells was also significantly higher than that observed after IVM for $18 \mathrm{~h}$. In contrast, the proportion of COCs from Control and Rosco with total cumulus expansion after IVM for $18 \mathrm{~h}$ significantly prevailed over that of partial expansion and compact cumulus cells. The rate of COCs with partial expansion did not significantly differ among treatments.

As shown in Table 3, almost all oocytes were at GV stage immediately after follicular aspiration $(0 \mathrm{~h})$. At $6 \mathrm{~h}$, the rate of oocytes maintained at GV with roscovitine was similar to that of Immature and significantly higher than that recorded in the corresponding Control. In contrast, the rate of oocytes from Control at GVBD and MI after culture for $6 \mathrm{~h}$ was significantly higher than that reported in the other treatments. After IVM for $18 \mathrm{~h}$, the percentage of oocytes from Control and Rosco that reached MII stage was significantly higher than that recorded at 0 and $6 \mathrm{~h}$. With respect to degenerate oocytes, no significant difference was observed among treatments.

\subsection{Experiment 2 - gene expression analysis}

The effect of roscovitine on gene expression in sheep cumulus cells is reported in Fig. 3. The expression level of BAX gene after treatment for $6 \mathrm{~h}$ with roscovitine was similar to that observed at $0 \mathrm{~h}$ but significantly lower than that of corresponding Control. After IVM for $18 \mathrm{~h}$, however, the relative abundance of this transcript in the Rosco treatment significantly increased and reached value greater than that of Control $6+18 \mathrm{~h}$. In contrast, the BCL2 mRNA level in the Control significantly increased after culture for a further $18 \mathrm{~h}$ but did not differ from Rosco $6+18 \mathrm{~h}$. The relative abundance of ALK5 transcript in the roscovitine treatment was down-regulated after IVM for $18 \mathrm{~h}$. However, the value reached was similar to that of Immature and Control treatments. With respect to PTX3 and ALK6 genes, the relative expression was significantly up-regulated in the Rosco and Control treatments after additional culture for $18 \mathrm{~h}$. No significant difference was observed among treatments regarding the expression of GLUT1, GREM1 and PTGS2 genes.

The pattern of gene expression in sheep oocytes treated for $6 \mathrm{~h}$ with roscovitine is shown in Fig. 4. The relative abundance of the ZAR1, NLRP5 and SOD1 transcripts was not affected by roscovitine, but was significantly down-regulated after IVM for $18 \mathrm{~h}$ in the Control and Rosco treatments. The mRNA levels for BAX and GDF9 in the Control significantly decreased after additional culture for $18 \mathrm{~h}$. The reached values, however, were similar to those recorded in the Rosco and Immature treatments. The BMP15 and BCL2 expression remained stable in all treatments.

\section{Discussion}

The spontaneous meiosis resumption of oocytes removed from their follicles interrupts the transcription and storage of RNAs required to proper maturation, fertilization and initial embryogenesis (Vigneron et al., 2004). This incomplete cytoplasmic maturity is one the most crucial factors affecting the potential of in vitro 
Table 2

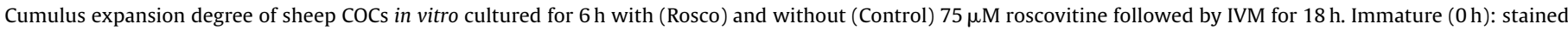
soon after aspiration.

\begin{tabular}{|c|c|c|c|c|c|}
\hline \multirow[t]{2}{*}{ Cumulus expansion degree } & \multicolumn{5}{|l|}{ Treatments, $n(\%)$} \\
\hline & Immature $(0 \mathrm{~h})$ & Control (6h) & $\operatorname{Rosco}(6 \mathrm{~h})$ & Control $(6+18 \mathrm{~h})$ & $\operatorname{Rosco}(6+18 h)$ \\
\hline Total & $0(0.0)^{\mathrm{bB}}$ & $0(0.0)^{\mathrm{bC}}$ & $0(0.0)^{\mathrm{bC}}$ & $67(57.8)^{\mathrm{aA}}$ & $62(59.6)^{\mathrm{aA}}$ \\
\hline Partial & $0(0.0)^{\mathrm{bB}}$ & $20(19.6)^{\mathrm{aB}}$ & $19(17.6)^{\mathrm{aB}}$ & $28(24.1)^{\mathrm{aB}}$ & $25(24.0)^{\mathrm{aB}}$ \\
\hline Absence & $122(100.0)^{\mathrm{aA}}$ & $82(80.4)^{\mathrm{bA}}$ & $89(82.4)^{\mathrm{bA}}$ & $21(18.1)^{\mathrm{cB}}$ & $17(16.3)^{\mathrm{cB}}$ \\
\hline No. COCs & 122 & 102 & 108 & 116 & 104 \\
\hline
\end{tabular}

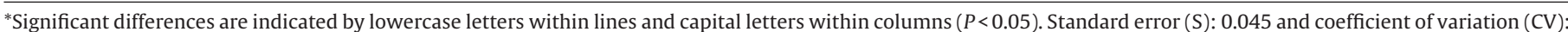
$5.0 \%$.

Table 3

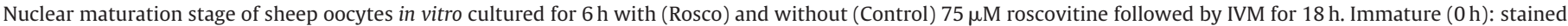
soon after aspiration.

\begin{tabular}{|c|c|c|c|c|c|}
\hline \multirow[t]{2}{*}{ Nuclear Maturation Stage } & \multicolumn{5}{|l|}{ Treatments, $n(\%)$} \\
\hline & Immature $(0 \mathrm{~h})$ & Control (6h) & $\operatorname{Rosco}(6 \mathrm{~h})$ & Control $(6+18 \mathrm{~h})$ & $\operatorname{Rosco}(6+18 \mathrm{~h})$ \\
\hline GV & $107(87.7)^{\mathrm{aA}}$ & $42(46.7)^{\mathrm{bA}}$ & $85(86.7)^{\mathrm{aA}}$ & $15(16.0)^{\mathrm{cB}}$ & $16(16.0)^{\mathrm{cB}}$ \\
\hline GVBD & $13(10.7)^{\mathrm{bB}}$ & $21(23.3)^{\mathrm{aB}}$ & $13(13.3)^{\mathrm{bB}}$ & $10(10.6)^{\mathrm{bBC}}$ & $11(11.0)^{\mathrm{bBC}}$ \\
\hline MI & $0(0.0)^{\mathrm{cc}}$ & $27(30.0)^{\mathrm{aB}}$ & $0(0.0)^{\mathrm{cC}}$ & $12(12.8)^{\mathrm{bB}}$ & $10(10.0)^{\mathrm{bBC}}$ \\
\hline MII & $0(0.0)^{\mathrm{bC}}$ & $0(0.0)^{\mathrm{bC}}$ & $0(0.0)^{\mathrm{bC}}$ & $56(59.6)^{\mathrm{aA}}$ & $59(59.0)^{\mathrm{aA}}$ \\
\hline Deg & $2(1.6)^{\mathrm{aBC}}$ & $0(0.0)^{\mathrm{aC}}$ & $0(0.0)^{\mathrm{aC}}$ & $1(1.1)^{\mathrm{ac}}$ & $4(4.0)^{\mathrm{ac}}$ \\
\hline No. oocyte & 122 & 90 & 98 & 94 & 100 \\
\hline
\end{tabular}

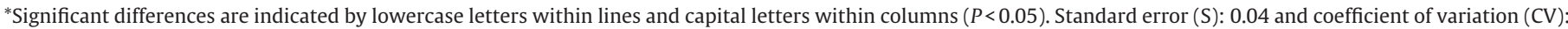
4.8\%. GV: germinal vesicle; GVBD: germinal vesicle breakdown; MI: metaphase I; MII: metaphase II, Deg: degenerate.

embryo development which is still low compared to that obtained in vivo (Rizos et al., 2002). In this context, attempts to arrest the meiosis in vitro with CDK inhibitors have been proposed in several species in order to provide additional time to oocyte capacitation (Mermillod et al., 2000; Han et al., 2006; Romar and Funahashi, 2006; Franz et al., 2003). However, the consequences of this artificial meiotic inhibition on gene expression of COCs have not been extensively investigated (Leal et al., 2012), especially in sheep.

So, the present study aimed to evaluate the effect of temporary meiotic arrest promoted by roscovitine on relative abundance of transcripts associated with developmental competence in sheep oocytes and cumulus cells. The absence of cumulus expansion in the immature COCs selected indicates that meiosis have not resumed in vivo (Dekel et al., 1981). According to Isobe et al. (1998), under gonadotropin stimulation, cumulus cells synthesize hyaluronic acid-rich matrix which is deposited into intercellular spaces, resulting in the rupture of Gap junctions between oocyte and cumulus cells, and consequent meiotic resumption. This process of cumulus expansion, however, occurs in a gradual manner. In appropriate supplemented medium, cumulus cells remain compacted until about $12 \mathrm{~h}$ of culture, when the expansion becomes evident and continuously increases up to end of culture (Hyttel et al., 1986). This kinetics of cumulus expansion was also observed in our study since no expansion occurred at $6 \mathrm{~h}$, but a significant rate of COCs had total cumulus expansion after IVM for $18 \mathrm{~h}$.

Our findings also demonstrate that some of investigated genes in cumulus cells had an expression profile consistent with the cumulus expansion pattern observed in the Control and Rosco treatments. The relative abundance of transcripts PTX3 (pentraxin 3) and ALK6 (actin receptor-like kinase 6) was significantly up-regulated at the end of $24 \mathrm{~h}$ culture. Similar expression pattern was observed for ALK6 in ovine oocytes in vitro matured (Kyasari et al., 2012). In bovine COCs, Assidi et al. (2008) also found basal expression of PTX3 at $6 \mathrm{~h}$ IVM, which, according to Wisniewski and Vilcek (2004), tends to increase until maximal cumulus expansion be achieved. With respect to PTGS2 (prostaglandin endoperoxide synthase 2), despite the evident expression after culture for a further $18 \mathrm{~h}$, it did not differ from that observed at 0 and $6 \mathrm{~h}$. The absence of PTGS2 mRNA variation during IVM was also reported by Kyasari et al. (2012) in sheep COCs. However, in the presence of EGF, a marked increase of PTGS2 mRNA was recorded in bovine oocytes (Vigneron et al., 2003).

In contrast, the relative abundance of transcripts ALK5 (actin receptor-like kinase 5) GREM1 (Gremlin), and GLUT1 (glucose transport 1) remained stable during this study. Similar ALK5 expression pattern was reported in sheep (Kyasari et al., 2012). However, the expression kinetics of GREM1 and GLUT1 during IVM has not yet been well established. The up-regulation of BCL2 MRNA and absence of variation of BAX mRNA observed in cumulus cells of Control after IVM for $18 \mathrm{~h}$ are in accordance with that reported by Filali et al. (2009) in human COCs. According to these authors, the ratio BCL2 (anti-apoptotic)/BAX (pro-apoptotic) determines cell survival, and the prevalence of BCL2 mRNA expression in cumulus cells is directly related to oocyte competence. While BCL2/BAX and Glut1 are involved, respectively, in the apoptosis control and glucose metabolism (Filali et al., 2009; Purcell and Moley, 2009), the others investigated genes (PTX3, PTGS2, ALK5 and ALK6) play important functions on cumulus expansion (Kyasari et al., 2012).

In cumulus cells treated with roscovitine, the up-regulation of BAX expression observed after additional culture for $18 \mathrm{~h}$ was followed by increase of BCL2 mRNA, which suggests that balance BCL2/BAX and consequent cellular viability were both maintained. Besides, the similarity between Control and Rosco treatments with respect to cumulus expansion and gene expression profile in cumulus cells indicates that roscovitine did not affect these events. Likewise, Leal et al. (2012) observed that transcripts pattern in cumulus cells of bovine COCs was unaffected by $100 \mu \mathrm{M}$ butyrolactone. However, Vigneron et al. (2003) reported that $25 \mu \mathrm{M}$ roscovitine reversibly inhibited the cumulus expansion and PTGS2 expression in bovine COCs even in the presence of EGF. These divergences among authors are probably related not only to drug concentration but also to inhibitor exposure time (Han et al., 2006; Sananmuang et al., 2010).

The high proportion of oocytes at GV stage (87.7\%) after follicle aspiration suggests that time interval for recovery and selection of COCs was adequate and did not induce the meiotic resumption before culture. Similar results were observed in goat (Han et al., 2006) and pig (Romar and Funahashi, 2006) oocytes. Moreover, 

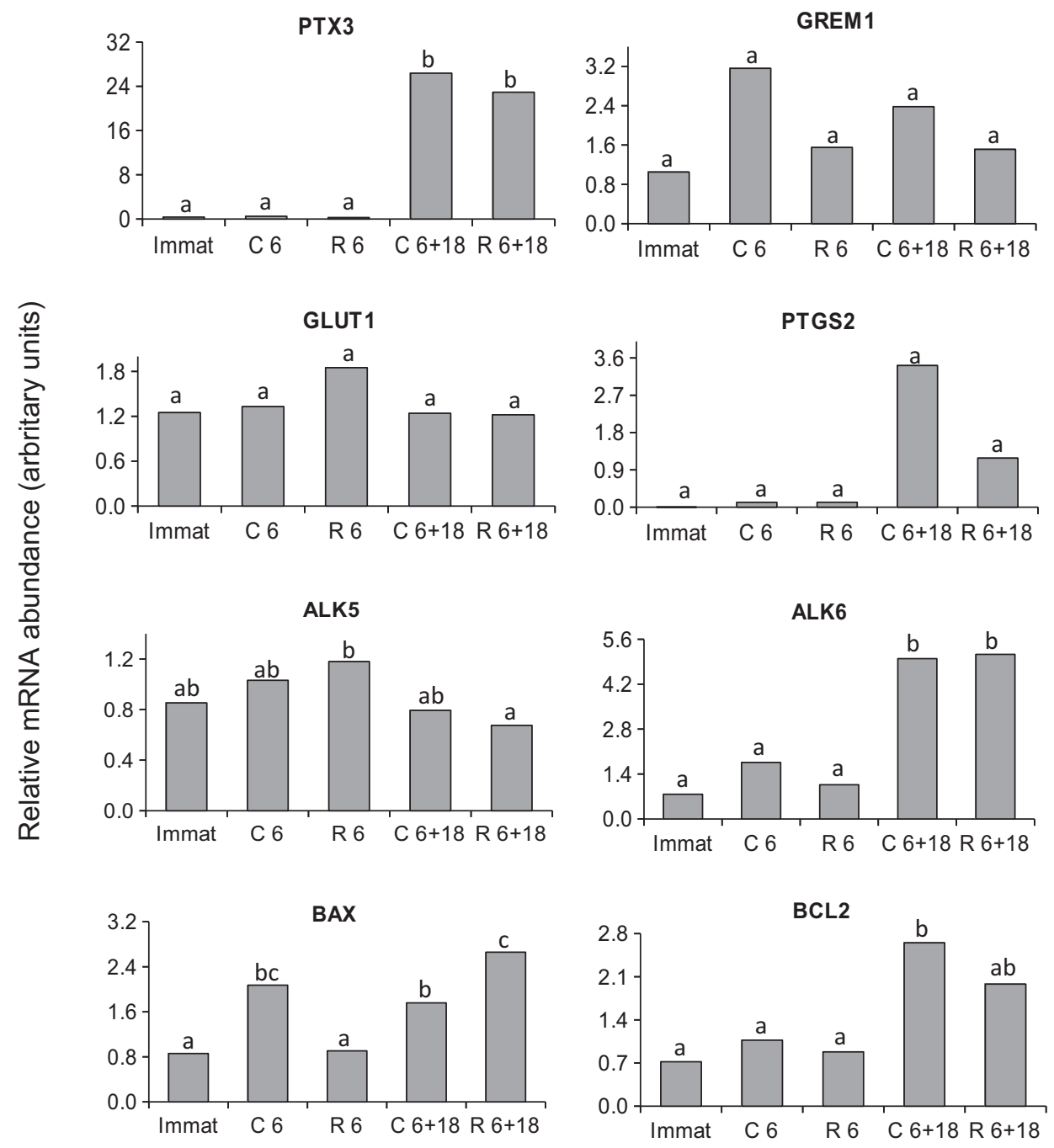

Treatments

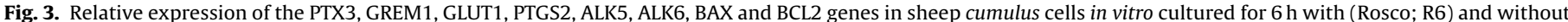

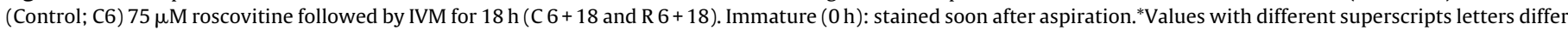
significantly $(P<0.05)$.

the significantly high rate of GV in the Rosco treatment in contrast to evident meiosis progression observed in the Control at $6 \mathrm{~h}$ of culture demonstrates that $75 \mu \mathrm{M}$ roscovitine was efficient to arrest the meiosis in sheep oocytes. This meiotic inhibition, however, was completely reversed and a significant rate of oocytes reached the MII after $18 \mathrm{~h}$ IVM. The reversible meiotic inhibition was also recorded in cat (Sananmuang et al., 2010), goat (Han et al., 2006), bovine (Mermillod et al., 2000) and horse (Franz et al., 2003) oocytes treated with roscovitine at different doses and exposure time. The low rate of degenerate oocytes also indicates that culture conditions were suitable.

With respect to gene expression profile in oocytes, the relative abundance of ZAR1 (zygote arrest 1), NLRP5 (PYD domains - containing protein 5, or MATER) and SOD1 (superoxide dismutase 1) was significantly down-regulated in the Control and Rosco treatments after IVM for $18 \mathrm{~h}$. Similarly, a significant decrease of ZAR1 and NLPR5 mRNA was reported by Bebbere et al. (2008) in sheep oocytes in vitro matured. However, the SOD1 mRNA level, which is considered crucial for protection against free radicals, remained stable in canine oocytes (Turathum et al., 2010). Presuming that reduction of mRNA levels indicate translation (Bebbere et al., 2008), the expression decrease of ZAR1, NLRP5 and SOD1 observed in our study suggests participation of these proteins during oocyte maturation. The maternal effect genes (ZAR1 and NLRP5) are still recognized by their importance during oocyte-embryo transition (Bebbere et al., 2008).

The significant decrease of GDF9 (growth and differentiation factor 9) expression during IVM for $18 \mathrm{~h}$ in contrast with stable BMP15 (bone morphogenetic protein 15) mRNA level observed in the Control is in accordance with that reported by Bebbere et al. (2008) in sheep oocytes. Probably, the expression profile of GDF9 is directly related to its function in the regulation of cumulus expansion and oocyte meiotic maturation (Reyes et al., 2013), while BMP15 seems to be more important in later development stages (Bebbere et al., 2008). Besides, the ratio BCL2/BAX observed in oocytes from Rosco and Control treatments reveals that cellular viability was maintained (Feugang et al., 2011) even in the presence of inhibitor.

The gene expression profile observed in our Control reinforces, therefore, the evidence that oocyte transcriptional activity is inter- 

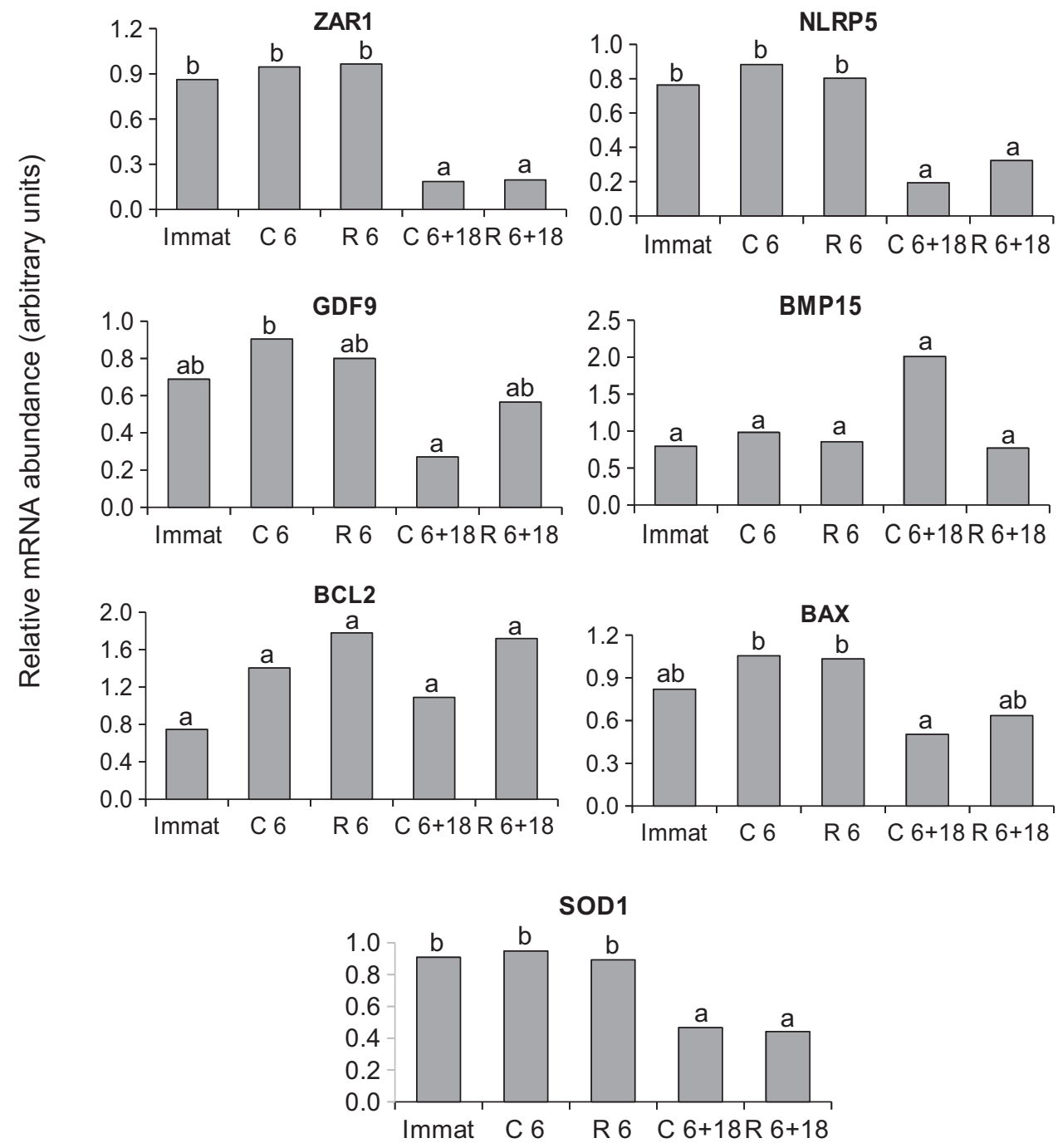

Treatments

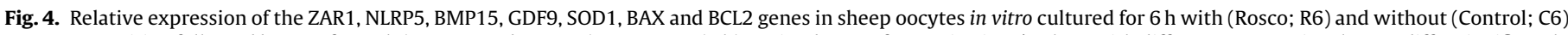

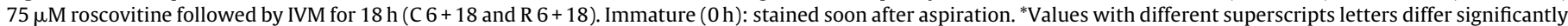
$(P<0.05)$.

rupted with meiosis resumption (Vigneron et al., 2004). According to these authors, maternal genes tend to remain stable or decline because of translation during IVM. Our findings also demonstrate that meiotic arrest promoted by roscovitine neither improved nor impaired the expression of investigated genes in sheep oocytes. Likewise, Leal et al. (2012) reported that most studied genes in bovine oocytes meiotically inhibited with butyrolactone had the same expression pattern of corresponding control. In contrast, significant increase of poly (A) mRNA content was reported by Lequarre et al. (2004) in bovine oocytes arrested at GV, which suggest neotranscription. However, in other cells types, roscovitine significantly suppressed the mRNA synthesis (Ljungman and Paulsen, 2001). We assumed that this discrepancy of results must be related to inhibition time, studied genes, methods of mRNA detection and species particularities.

The efficiency of temporary meiotic arrest and absence of deleterious effect on cumulus expansion, nuclear maturation and gene expression also suggest that roscovitine provides a useful and efficient method for transportation or manipulation of sheep COCs at onset of maturation. Furthermore, the maintenance of oocytes at GV stage may have a great impact on research and commercial application considering that oocytes sometimes are collected in places far from laboratory and their viability is limited (Hashimoto et al., 2003). According to Gharibi et al. (2013), the temporary arrest of meiosis also has implication in the synchronization of oocyte maturation and improvement of in vitro oocyte developmental competence.

In conclusion, we can infer that roscovitine, at the concentration and exposure time studied, was efficient to reversibly arrest the meiosis in sheep oocytes without negatively affect or improve the cumulus expansion and the relative abundance of investigated transcripts. Further investigations have been performed to evaluate the benefits of roscovitine treatment on in vitro development of sheep embryos and its effects on cellular ultrastructure.

\section{Acknowledgement}

This work was supported by Fundação de Amparo à Pesquisa do Estado de São Paulo (São Paulo Research Foundation - FAPESP), Brazil (2011/14041-5, 2011/18843-9). 


\section{References}

Andraszek, K., Smalec, E., 2011. Structure and functions of lampbrush chromosomes. J. Biotechnol. Comput. Biol. Bionanotechnol. 92, 337-344.

Assidi, M., Dufort, I., Ali, A., Hamel, M., Algriany, O., Dielemann, S., Sirard, M., 2008. Identification of potential markers of oocyte competence expressed in bovine cumulus cells matured with follicle-stimulating hormone and/or phorbol myristate acetate in vitro. Biol. Reprod. 79, 209-222.

Bebbere, D., Bogliolo, L., Ariu, F., Fois, S., Leoni, G.G., Tore, S., Succu, S., Berlinguer, F., Naitana, S., Ledda, S., 2008. Expression pattern of zygote arrest 1 (ZAR1) maternal antigen that embryo requires (MATER), growth differentiation factor 9 (GDF9) and bone morphogenetic protein 15 (BMP15) genes in ovine oocytes and in vitro-produced preimplantation embryos. Reprod. Fert. Dev. 20, 908-915.

Brevini-Gandolfi, T.A.L., Gandolfi, F., 2001. The maternal legacy to the embryo: cytoplasmic components and their effects on early development. Theriogenology 55, 1255-1276.

Crocomo, L.F., Marques Filho, W.C., Ulian, C.M.V., Branchini, N.S., Silva, D.T., Ackermann, C.L., Landim-Alvarenga, F.C., Bicudo, S.D., 2015a. Effect of oil overlay on inhibition potential of roscovitine in sheep cumulus-oocyte complexes. Reprod. Domest. Anim. 50 (3), 410-416.

Crocomo, L.F., Ulian, C.M.V., Branchini, N.S., Silva, D.T., Marques Filho, W.C., Landim-Alvarenga, F.C., Bicudo, S.D., 2015b. Meiotic arrest of sheep oocytes using roscovitine under different medium compositions. Small Rumin. Res. 126, 52-58.

Crocomo, L.F., Marques Filho, W.C., Ackermann, C.L., Paschoal, D.M., Guastali, M.D., Maziero, R.R.D., Sudano, M.J., Landim-Alvarenga, F.C., Bicudo, S.D., 2015c. Time course of the meiotic arrest in sheep cumulus-oocyte complexes treated with roscovitine. Zygote 14, 1-9.

Dekel, N., Lawrence, T.S., Gilula, N.B., Beers, W.H., 1981. Modulation of cell-to-cell communication in the cumulus-oocyte complex and the regulation of oocyte maturation by LH. Dev. Biol. 86, 356-392.

Ferreira, E.M., Vireque, A.A., Adona, P.R., Meirelles, F.V., Ferriani, R.A., Navarro, P.A.A.S., 2009. Cytoplasmic maturation of bovine oocytes: structural and biochemical modifications and acquisition of developmental competence. Theriogenology 71, 836-848.

Feugang, J.M., Greene, J.M., Willard, S.T., Ryan, P.L., 2011. In vitro effects of relaxin on gene expression in porcine cumulus-oocyte complexes and developing embryos. Reprod. Biol. Endocrinol. 9, 2-10.

Filali, M., Frydman, N., Belot, M.P., Hesters, L., Gaudin, F., Tachdjian, G., Emilie, D., Frydman, R., Machelon, V., 2009. Oocyte in vitro maturation: BCL2 mRNA content in cumulus cells reflects oocyte competency. Reprod. Biomed. Online $19,72-84$.

Franz, L.C., Choi, Y.H., Squires, E.L., Seidel, G.E., Hinrichs, K., 2003. Effects of roscovitine on maintenance of the germinal vesicle in horse oocytes, subsequent nuclear maturation, and cleavage rates after intracytoplasmic sperm injection. Reproduction 125, 693-700.

Gharibi, S., Hajian, M., Ostadhosseini, S., Hosseini, S.M., Forouzanfar, M., Nasr-Esfahani, M.H., 2013. Effect of phosphodiesterase type 3 inhibitor on nuclear maturation and in vitro development of ovine oocytes. Theriogenology 80, 302-312

Gilchrist, R.B., Thompson, J.G., 2007. Oocyte maturation: emerging concepts and technologies to improve developmental potential in vitro. Theriogenology 67, 6-15.

Han, D., Lan, G., Wu, Y., Han, Z., Wang, H., Tan, J., 2006. Factors affecting the efficiency and reversibility of roscovitine (ros) block on the meiotic resumption of goat oocytes. Mol. Reprod. Dev. 73, 238-246.

Hashimoto, S., Kimura, K., Iwata, H., Takakura, R., 2003. Oocyte transport: developmental competence of bovine oocytes arrested at germinal vesicle stage by cycloheximide under air. J. Reprod. Dev. 49, 61-62.

Heidari Amale, M., Zare Shahne, A., Abavisani, A., Nasrollahi, S., 2011. Effects of inhibiting nitric oxide synthase on cumulus expansion and nuclear maturation of sheep oocytes. Czech J. Anim. Sci. 56 (6), 284-291.

Hyttel, P., Xu, K.P., Smith, S., Greve, T., 1986. Ultrastructure of in vitro oocyte maturation in cattle. J. Reprod. Fert. 78, 615-625.

Isobe, N., Maeda, T., Terada, T., 1998. Involvement of meiotic resumption in the disruption of gap junctions between cumulus cells attached to pig oocytes. J. Reprod. Fert. 113, 167-172.
Kyasari, O.R., Valojerdi, M.R., Farrokhi, A., Ebrahimi, B., 2012. Expression of maturation genes and their receptors during in vitro maturation of sheep COCs in the presence and absence of somatic cells of cumulus origin. Theriogenology 77, 12-20.

Leal, C.L., Mamo, S., Fair, T., Lonergan, P., 2012. Gene expression in bovine oocytes and cumulus cells after meiotic inhibition with the cyclin-dependent kinase inhibitor butyrolactone I. Reprod. Domest. Anim. 47, 615-624.

Lequarre, A.S., Traverso, J.M., Marchandise, J., Donnay, I., 2004. Poly(A) RNA is reduced by half during bovine oocyte maturation but increases when meiotic arrest is maintained with cdk inhibitors. Biol. Reprod. 71, 425-431.

Ljungman, M., Paulsen, M.T., 2001. The cyclin-dependent kinase inhibitor roscovitine inhibits RNA synthesis and triggers nuclear accumulation of p53 that is unmodified at Ser15 and Lys382. Mol. Pharmacol. 60, 785-789.

Mehlmann, L.M., 2005. Stops and starts in mammalian oocytes: recent advances in understanding the regulation of meiotic arrest and oocyte maturation. Reproduction 130, 791-799.

Meijer, L., Borgne, A., Mulner, O., Chong, J.P.J., Blow, J.J., Inagaki, N., Inagaki, M., Delcros, J.G., Moulinoux, J.P., 1997. Biochemical and cellular effects of roscovitine, a potent and selective inhibitor of the cyclin-dependent kinases cdc2, cdk2 and cdk5. Eur. J. Biochem. 243, 527-536.

Mermillod, P., Tomanek, M., Marchal, R., Meijer, L., 2000. High developmental competence of cattle oocytes maintained at the germinal vesicle stage for $24 \mathrm{~h}$ in culture by specific inhibition of MPF kinase activity. Mol. Reprod. Dev. 55, 89-95.

Pfaffl, M.W., 2001. A new mathematical model for relative quantification in real-time RT-PCR. Nucleic Acids Res. 29, 2002-2007.

Pincus, G., Enzmann, E.V., 1935. The comparative behavior of mammalian eggs in vivo and in vitro. J. Exp. Med. 62, 665-675.

Purcell, S.H., Moley, K.H., 2009. Glucose transporters in gametes and preimplantation embryos. Trends Endocrin. Met. 20, 483-489.

Ramakers, C., Ruijter, J.M., Deprez, R.H., Moorman, A.F., 2003. Assumption-free analysis of quantitative real-time polymerase chain reaction (PCR) data. Neurosci. Lett. 339, 62-66.

Reyes, M.D.L., Rojas, C., Parraguez, V.H., Palomino, J., 2013. Expression of growth differentiation factor 9 (GDF-9) during in vitro maturation in canine oocytes. Theriogenology 80, 587-596.

Rizos, D., Lonergan, P., Ward, F., Duffy, P., Boland, M.P., 2002. Consequences of bovine oocyte maturation, fertilization or early embryo development in vitro versus in vivo: Implications for blastocyst yield and blastocyst quality. Mol. Reprod. Dev. 61, 234-248.

Romar, R., Funahashi, H., 2006. In vitro maturation and fertilization of porcine oocytes after a $48 \mathrm{~h}$ culture in roscovitine, an inhibitor of p34cdc2/cyclin B kinase. Anim. Reprod. Sci. 92, 321-333.

Sananmuang, T., Techakumphu, M., Tharasanit, T., 2010. The effects of roscovitine on cumulus cell apoptosis and the developmental competence of domestic cat oocytes. Theriogenology 73, 199-207.

Shirazi, A., Shams-Esfandabadi, N., Ahmadi, E., Heidari, B., 2010. Effects of growth hormone on nuclear maturation of ovine oocytes and embryo. Reprod. Domest. Anim. 45, 530-536.

Sirard, M.A., 2001. Resumption of meiosis: mechanism involved in meiotic progression and its relation whit developmental competence. Theriogenology $55,1241-1254$

Sugiura, K., Eppig, J.J., 2005. Control of metabolic cooperativity between oocytes and their companion granulosa cells by mouse oocytes. Reprod. Fert. Dev. 17, 667-674.

Turathum, B., Saikhun, K., Sangsuwan, P., Kitiyanant, Y., 2010. Effects of vitrification on nuclear maturation, ultrastructural changes and gene expression of canine oocytes. Reprod. Biol. Endocrinol. 8, 2-9.

Vigneron, C., Nuttinck, F., Perreau, C., Reinaud, P., Charpigny, G., Mermillod, P., 2003. Effect of roscovitine, a cdk1 inhibitor, and of the presence of oocyte on bovine cumulus cell expansion and cyclooxygenase-2 expression. Mol. Reprod. Dev. 65, 114-121.

Vigneron, C., Perreau, C., Dalbies-Tran, R., Joly, C., Humblot, P., Uzbekova, S., Mermillod, P., 2004. Protein synthesis and mRNA storage in cattle oocytes maintained under meiotic block by roscovitine inhibition of MPF activity. Mol. Reprod. Dev. 69, 457-465

Wisniewski, H.G., Vilcek, J., 2004. Cytokine-induced gene expression at the crossroads of innate immunity, inflammation and fertility: TSG-6 and PTX3/TSG-14. Cytokine Growth Factor Rev. 15, 129-146. 